IZA DP No. 5806

Career Changers in Teaching Jobs: A Case Study Based on the Swiss Vocational Education System

Stefanie Hof

Mirjam Strupler

Stefan C. Wolter

June 2011 


\title{
Career Changers in Teaching Jobs: A Case Study Based on the Swiss Vocational Education System
}

\author{
Stefanie Hof \\ Swiss Coordination Centre for Research in Education (SKBF) \\ Mirjam Strupler \\ University of Bern \\ Stefan C. Wolter \\ University of Bern, \\ SKBF, CESifo and IZA
}

Discussion Paper No. 5806
June 2011

IZA

P.O. Box 7240

53072 Bonn

Germany

Phone: +49-228-3894-0

Fax: +49-228-3894-180

E-mail: iza@iza.org

Any opinions expressed here are those of the author(s) and not those of IZA. Research published in this series may include views on policy, but the institute itself takes no institutional policy positions.

The Institute for the Study of Labor (IZA) in Bonn is a local and virtual international research center and a place of communication between science, politics and business. IZA is an independent nonprofit organization supported by Deutsche Post Foundation. The center is associated with the University of Bonn and offers a stimulating research environment through its international network, workshops and conferences, data service, project support, research visits and doctoral program. IZA engages in (i) original and internationally competitive research in all fields of labor economics, (ii) development of policy concepts, and (iii) dissemination of research results and concepts to the interested public.

IZA Discussion Papers often represent preliminary work and are circulated to encourage discussion. Citation of such a paper should account for its provisional character. A revised version may be available directly from the author. 


\begin{abstract}

\section{Career Changers in Teaching Jobs: A Case Study Based on the Swiss Vocational Education System*}

This study investigates the determinants and motives of professionals who change career to vocational teaching. The framework for this study is the Swiss vocational education system, which requires that teachers of vocational subjects must have a prior career in that specific field. Thus, to work in teaching, every vocational teacher has to change his or her initial career. This paper focuses on the relevance of monetary motives for changing a career to teaching. Using a unique data set of trainee teachers, we show that professionals who change their careers to teaching earned on average more in their first career than comparable workers in the same occupation. Our findings additionally demonstrate that the average career changer still expects to earn significantly more as a teacher than in the former career. However, the study shows substantial heterogeneity and a zero wage elasticity of the teacher supply, suggesting that non-monetary motives are more relevant for career change than monetary factors.
\end{abstract}

JEL Classification: $\quad$ C21, I20, J24, J45, J62

Keywords: career change, occupational change, rate of return to education, wage differentials, teacher wages, vocational education and training

Corresponding author:

Stefan C. Wolter

University of Bern

Department of Economics

Centre for Research in Economics of Education

Schanzeneckstrasse 1

P.O. Box 8573

$\mathrm{CH}-3001$ Bern

Switzerland

E-mail: stefan.wolter@vwi.unibe.ch

\footnotetext{
* The authors wish to thank Jean-Louis Berger and co-workers at the Swiss Federal Institute for Vocational Education and Training (SFIVET) for their cooperation in generating the data. The authors also wish to express their thanks for the funding supplied by the Federal Office for Professional Education and Technology (BBT/OPET) and the Swiss Leading House "Economics of Education" of the Universities of Zurich and Bern.
} 


\section{Introduction}

Most employees in industrialized countries today change careers and occupations at least once in their working lives (see, e.g., Kambourov \& Manovskii, 2008; Longhi \& Brynin, 2010; Parrado et al., 2007; Sheldon, 2005). Understanding the determinants and the consequences of career change is therefore critical for individuals, organizations, and policy makers. However, one of the inherent difficulties in empirical analyses of career and occupational change is that a career move can be observed among workforce members who have changed careers but not among those who have not. Thus, when comparing career changers and non-changers, we are not able to know whether the nonchangers would ever have considered changing to the careers that the changers chose to enter. To overcome this difficulty a number of studies have investigated the probability of leaving a specific career as a function of the attractiveness of potential alternative careers (e.g., Longhi \& Brynin, 2010; Rubinstein \& Weiss, 2006). In contrast, this study investigates the determinants governing change to a specific career (teaching) as a function of its relative attractiveness, i.e. whether changing a career to teaching is more attractive than staying in the original occupation. Given current teacher shortages in Switzerland the question of what motivates professionals in general and vocational in particular to become teachers is important indeed.

More specifically, we use a particular feature of the Swiss vocational education and training (VET) system to study career change--that teachers of job-related subjects cannot choose teaching as their first career but can only become teachers after (a) acquiring the highest education qualification in their job category and (b) accumulating a certain number of years of job experience. Thus, all teachers of vocational subjects have changed careers.

Switzerland is one of the OECD countries with both the highest proportion of young people opting for VET for upper secondary education and the highest proportion of young people choosing the dual system, i.e., vocational school plus on-the-job training (Wolter \& Ryan, 2010). Thus, given the size and the importance of the vocational sector in the Swiss education system, in qualitative and quantitative terms answering the question of who chooses to leave his or her former career to become a vocational school teacher is important.

For our empirical analyses we assess a unique data set of teacher trainees who decided to change careers to teaching. The data set is representative for the whole of German- and French-speaking Switzerland. For our comparative analyses we use data on the workforce from the Swiss Labor Force Survey (SLFS).

Our results show that those who change careers to teaching and who are on average 40 years old do 
not change careers because of lack of (financial) success in their original career. While the results are not surprisingly heterogeneous we can nevertheless explain at least part of this heterogeneity. Although the average teacher tends to rank among the better earners in the original career, the majority of career changers expect to earn more as a teacher than in the original career. However, we again find a substantial heterogeneity: Around one-third of career changers accept wage reduction after changing. And finally, we do not find a positive significant wage elasticity of the teacher supply.

The next section contextualizes our research with a description of the recruiting procedures for Swiss vocational education and training teachers, followed by a brief review of the literature. Section 4 describes our data and outlines our research questions, section 5 presents the empirical results and section 6 concludes with a discussion of our results.

\section{Recruitment of vocational teachers in Switzerland}

The legal provisions governing the hiring of teachers for instruction in vocational subjects require candidates to meet two conditions: First, candidates must have the highest possible training qualification in the particular profession (Federal Vocational and Professional Education and Training Act [BBG] Art. 46, 2), which in most cases is a professional education at tertiary level B (ISCED 5B) or even an academic degree at tertiary level A (ISCED 5A). Second, they must have very good subject knowledge, i.e., a minimum of six months (BBG Art. 46, 1) of job experience, with several years being the norm. Most teachers have a long history of job experience, because the highest possible training qualification generally consists of practically oriented and occupationally specific training at an advanced level (57\% of prospective teachers in our sample have tertiary level B professional education and training), all of which involves many years of job experience. Extensive job experience is also apparent in our sample, with the average age teacher trainees being over 40 (see table 1).

However, the sample also contains prospective teachers whose highest previous educational qualification was upper secondary $(8 \%)$. Either these teachers come from professions with no tertiary education programs, or the vocational school recruited the teachers despite their low academic qualifications because of a shortage of teachers in a particular field.

Another career changing condition that professionals interested in teaching must meet is that a vocational school must recruit them. Changing to a teaching career therefore takes place in two stages: First, the vocational school recruits prospective teachers and establishes that they are suitable for the profession to the fullest possible extent in terms of expertise, personality, and aptitude. 
Second, individuals begin teacher training for full-time or "sideline" positions. Full-time teacher can work full-time or part-time teaching at vocational schools. "Sideline" teachers, by contrast, consists of many fewer training hours and therefore their certificate limits them to teaching part-time, not fulltime. We use the term "sideline teachers" to distinguish these teaching professionals from those who are trained for full-time teaching but who may choose to teach part-time. For sideline teachers, their work is precisely that--a "sideline" of their professional work in their original field. Although it is common for interested parties to begin with sideline teacher training and later switch to full-time teaching, the majority of full-time prospective teachers in our sample began full-time teacher training from the start.

Throughout their training, teacher trainees teach part-time at a vocational school, thereby enabling them to apply academic knowledge immediately in real-life teaching practice and transfer real-life teaching issues to their studies, while discovering whether they are truly cut out to be teachers. Some cantons (the equivalent of states in the US) recompense trainees for the opportunity cost of trainingi.e., reduced working hours due to training commitments-in the form of a wage, while other cantons expect trainees to carry the cost themselves. As in other types of education, one feature of teaching at vocational schools is that all teachers receive the same wage (depending, however, on age, canton, experience and training), whatever their original occupation.

The prospective teachers are recruited from professions and industries being taught to students at the schools, that is the original occupations of the teaching staff reflect the respective apprenticeship market. This market also explains why one-third of vocational teachers are from industry, trade, and construction. One crucial factor directly affecting the appeal of teaching at vocational schools is the competitiveness of the original occupations and business sectors in terms of the prevailing pay and working conditions.

At the time of this study, three higher education institutions were offering vocational teacher training in Switzerland, however,the Swiss Federal Institute for Vocational Education and Training (SFIVET), which provided the sample used for this paper, has a market share of over $80 \%$ of vocational teacher trainees.

\section{Literature review}

For our hypotheses, we use two sets of theoretical and empirical studies: (a) highly specific literature focusing on self-selection to the teaching profession and examining who opts for teaching and what their motives are and (b) career change-specific literature. Rather than being restricted to a specific 
career type, the career change literature explores the factors predictive of career change in general and identifies who is more likely to change careers or who does not.

a) Literature on self-selection to the teaching profession

The existing literature on the choice of teaching as a (first) career both investigates factors governing candidate quality and factors governing the quantity of teachers available in the workforce. Economic literature tends to focus in relative wage as a factor influencing the quantitative and qualitative supply of teachers on the labor market. Non-monetary factors have also been studied but only to some extent because these factors are usually much more difficult to address empirically.

Most studies demonstrate positive wage elasticity of teacher labor supply (Chevalier et al., 2007; Dolton, 1990; Dolton \& Chung, 2004; Falch, 2010; Manski, 1987; Wolter \& Denzler, 2004). Comparing studies from different countries is relatively difficult because the relative wage position of teachers in the overall wage structure and the educational qualifications required for becoming a teacher differ significantly across countries. Studies from English-speaking countries show significantly higher wage elasticity of labor supply for teachers than that in the only Swiss study on this topic (Wolter et al., 2003). These findings may be related to labor supply elasticity`s being influenced to some extent by how high the wage differential is in absolute terms. Labor supply elasticity appears very high in cases where teachers earn less than individuals in similar professions, whereas elasticity is relatively low where teachers tend to earn more.

For qualitative selection to the teaching profession, the results of known empirical studies are less conclusive and research does not know much about the factors (monetary and non-monetary working conditions, social status, etc.) that determine positive selection to the teaching profession in qualitative terms.

Whereas US studies find ample evidence of negative selection in terms of cognitive criteria (see, e.g., Hanushek \& Pace, 1995; Manski, 1987; Murnane et al., 1991; Podgursky et al., 2004; Stinebrickner, 2001), the results are less clear-cut for German-speaking countries (for a recent literature review see Denzler \& Wolter, 2009a). Furthermore, depending on the education system, self-selection depends not only on differences in job market prospects but also on the different training qualifications: In a Swiss study, Denzler and Wolter (2009b) show that school leavers who seek a short course of studies and are less interested in research work tend to choose mainly the shorter and (presumably) less intellectually demanding training at universities of teacher education (compared with studying at a traditional academic university).

However, the findings in studies investigating qualitative selection, that there is a risk of a negative 
selection as regards cognitive and non-cognitive abilities or career choice motives may not necessarily mean that this also has a negative impact on how well a person teaches.

Along with the difficulty of applying empirical data across countries is that of applying data relevant to selection of teachers for basic, compulsory education to other educational levels and sectors. However, what makes applying these data most difficult to the subject matter explored in this paper is, that all these studies focus on why people select teaching as a first career after graduation, whereas regarding the question why people select teaching as a second career there is a poverty of comparable empirical studies.

\section{b) Literature on career change}

Standard search and matching models (Burdett, 1978; Jovanovic, 1979; Mortensen, 1986; Neal, 1999) depart from assuming that labor markets feature heterogeneous employers and employees, and imperfect information. Employee productivity is highest in the presence of the perfect match to the specific job. Since neither employer nor employee will know the optimal match in advance, employees will keep changing jobs until they achieve the perfect match. As a consequence of this search process, changing jobs correlates with increasing wages (Rubinstein \& Weiss, 2006). Nonetheless, people do not continuously go about changing employers and careers because any change involves a loss of human capital and, therefore of productivity and wage.

According to classical human capital theory (Becker, 1962), jobs are associated with the acquisition of employer-, occupation-, and industry-specific human capital that is forfeited with a change of employer or - and even more so - a change of career. The better match in the new job would therefore have to raise the productive value of general human capital enough to compensate for the loss in employer- and job-specific human capital. Corresponding to the logic of the human capital theory, a change is all the more unlikely the longer the period of investment in employer- and jobspecific human capital has been. One should therefore be able to observe a lower incidence of job changes (with or without career changes) as a function of seniority.

Refinements of the human capital theory (e.g., the skills weight theory, see Lazear, 2009) assume the existence of no general or specific human capital but only of different combinations of skills. These refinements suggest that, regardless of the existing duration of employment, mobility between employers, professions, and industries can still be high, provided that the potential employment alternative requires a similar mix of skills (see, e.g., Geel et al., 2010).

For our hypotheses, this additional factor is relevant because a vocational teacher's job not only calls for levels of expertise similar to those required in the former occupation but also requires aboveaverage expertise levels (i.e., a long history of skill-building) in the original occupation. As we can 
assume that a large part of the expertise accumulated in the former occupation can be transferred to the new one (teaching) it is not likely that the probability of changing career to teaching will correlate negatively with seniority. In contrast, individuals who changed employers frequently also tend to be those who have already changed careers once or several times. The lack of consistency in their employment history makes it more difficult for these individuals to enter the vocational teaching profession.

As to making hypotheses based on search and matching models, individuals will want to change to that profession only if they are hoping it will be a better match, that is to say that they will be more productive in the new job. However, the extent to which a higher wage is expected to be part of that better match is remains unclear. The reason is first, that we do not know the relative position of different jobs regarding the non-monetary benefits. Second the assumption that higher productivity will translate to a higher wage does not automatically apply in the public sector, where schooling takes place.

\section{Data and research strategy}

\subsection{Data}

We conducted the survey among all teacher trainees for vocational teaching for full-time and sideline positions at Swiss Federal Institute for Vocational Education and Training (SFIVET) during spring semester 2010 in cooperation with SFIVET. As we conducted the survey during classes, we achieved a response rate of $100 \%$. Given SFIVET's over $80 \%$ market share, the survey is representative for both German- and French-speaking Switzerland. The teacher trainees completed the survey using either a computer-assisted questionnaire or, if no computer was available, an identical paper and pencil version. We tested the questionnaire in an extensive pre-test on teachers and trainers who had previously trained at SFIVET.

The information elicited in the survey comprises personal details, training, job experience, wage, and wage expectations of the 483 respondents in German- and French-speaking Switzerland. About one half of the 483 teacher trainees (230) were pursuing a degree qualifying them as full-time vocational teachers. The other half respondents (253) were working toward a certificate qualifying them as sideline vocational teachers. Despite the $100 \%$ response rate, some data were missing due to item non-response. We excluded 93 observations (19\%) from the analysis because of missing wage information or other important data, leaving a final dataset of 390 vocational teacher trainees. Item non-response analyses show that the exclusion of the 93 observation should not influence or bias our 
results. ${ }^{1}$

We sourced the comparison group data from the SLFS. As the trainee vocational teachers opted to change to teaching at different times, we had to use three different cohorts $(2004,2006$, and 2008) of the labor force survey. To obtain the comparison group for the teacher trainees, we excluded all individuals who would not have been able to become a teacher, i.e., the unemployed, pensioners, students, individuals without post-compulsory-schooling qualifications, and individuals who were under 20 year olds prior to our analyses. Details of each of the variables for vocational teacher trainees and SLFS subjects appear in table 1.

\title{
[Table 1]
}

\subsection{Research strategy}

Using the data from the teacher trainee survey and data from the SLFS, this paper investigates three factors empirically: (a) the background of the prospective teachers compared to former colleagues who have decided to remain in the original occupation, (b) the individual wage expectations of career changers, and (c) the wage elasticity of the teacher supply for vocational subjects.

\section{(a) Teachers' backgrounds}

This section determines how much the trainees had earned relative to others in their original occupation. This analysis shows us whether those who choose teaching earn an average wage in their former profession or constitute a positive or negative selection out of it.

\begin{abstract}
Although automatically inferring suitability for teaching from what a person earned in their original occupation is not possible, a somewhat more direct relationship nonetheless exists between productivity in the former occupation and suitability for vocational teaching than might apply to other teaching categories or professions. The main task of vocational teachers is to teach young people occupation-specific knowledge relevant to the teacher's former occupation. Therefore, if we assume that individuals whose skills are above average in their original occupation are more productive and earn commensurately more (except for in the public sector), then positive selection should also be beneficial to vocational education. Positive selection would imply that the prospective teachers tended to earn more than their peers in their original occupation.
\end{abstract}

\footnotetext{
${ }^{1}$ To determine whether the non-responses might have introduced a bias into the observed wage and wage expectations data, we did a two-tailed non-response analysis. A probit analysis of the non-responses revealed significant over-representation of nonresponses in specific regions but revealed no other personal characteristics that might have explained the non-responses. To test whether the over- or under-representation of individual regions in the responses affected the wage analysis, we performed a second regression in which we imputed the missing wage details with a multiple wage regression. Comparison between the imputed and non-imputed wages (results available upon request) shows that, individuals with missing wage data do not differ significantly from individuals who supplied their wage details. Expected alternative wages five years after training constitute an exception: imputed wages at a $10 \%$ level of significance are significantly lower than the wages from the responses.
} 
Our analysis is a form of inversion of that of Chingos and West (2010), who investigate whether, of teachers who left teaching, those who earned more in the new profession had also been the better teachers (i.e., obtained better student performance). They identified a positive correlation which they interpreted as indicating that the same skills that made this group of teachers more productive in the educational system also led to higher productivity in other professions.

We identify a comparison group by matching with individuals from the SLFS who do not differ from our subjects in terms of key (observable) characteristics. To do so, we use exact matching as described by Abadie et al. (2004).

Given the four assumptions that (a) a correlation exists between professional competence and wage, (b) the hiring authority (usually the head teacher) imputes a correlation between professional competence and teaching competence, (c) the hiring authority is in a position to choose among different candidates, and (d) teaching wages are competitive on average with other wages, our first hypotheses is that our trainee teacher sample should include more people who were among the higher earners in their original occupation - provided that the basic assumption that teaching and the alternative professions can be compared in terms of non-monetary working conditions holds true.

The fourth assumption, i.e., that teachers' wages are, on average, competitive with other wages, will not be equally met for all professional sectors and industries. Therefore, a second hypothesis states that individuals have less of an incentive to change to teaching from professions and industries with an average wage as high as or higher than in teaching. Accordingly, prospective teachers from these professions and industries would count among the lower earners in their sector, while exactly the opposite would apply in less well-paid professions and industries.

To test these hypotheses, we attempt to identify factors that may explain whether a trainee teacher earned more or less than his or her exact peers in their original occupation.

(b) Teachers' wage expectations

This section investigates the wage prospects of career changers who have opted to become teachers. Whatever their relative position on the wage scale, prospective teachers can earn more or less as teachers than they would have earned had they decided to stay in their former occupation.

Those who opt to become teachers are unlikely to represent a random sample of all individuals who could theoretically become teachers. Thus, a simple comparison of teachers' wages with average alternative wages is not a useful way of learning whether the decision to change to teaching pays off 
financially. This study explores the counterfactual situation to the decision to become a teacher in surveying teacher trainees' expectations on both options. The questionnaire asked teacher trainees to indicate their wage expectations for two scenarios: first, expected wages (5 and 10 years after training) if they stay in teaching, and second, expected wages had they continued to work in their original occupation.

Whether these wage expectations are indeed accurate ex post is irrelevant to what is at stake here, i.e., selection to the teaching profession. What matters is the expectations of individuals who decided to enter teaching, at the time they made those decisions (ex ante). In accordance with search and matching models, one expects the average prospective teacher to expect a monetary benefit from the change. A conscious decision to accept a monetary disadvantage from the decision to enter teaching likely occurs only in cases in which the relative non-monetary benefits of teaching are high enough to more than compensate for the monetary disadvantages.

c) Wage elasticity of teacher supply

The final section explores whether the probability of changing to teaching depends on the relative wage difference between teaching and an alternative profession (wage elasticity of teacher supply). This issue is important because the results provide a basis for estimating the impact that a wage increase for vocational teachers will have on the quantity of available candidates. The empirical approach is the same as that in existing studies on this topic for other teacher categories (see, e.g., Chevalier et al., 2007; Dolton, 1990; Wolter \& Denzler, 2004): We calculate an individual wage differential for the alternatives "teaching" $\left(\mathrm{W}^{\mathrm{T}}\right)$ and "other profession" $\left(\mathrm{W}^{\mathrm{A}}\right)$ for teachers and nonteachers, respectively. We then use this individual wage differential as an explanatory variable in a probit estimate (see equation 1). The variable $T$ assumes a value of 1 if the individual opted to change to teaching and 0 if not. $\mathrm{X}$ is a vector that integrates a number of other explanatory variables.

$T_{t}=\beta_{0}+\beta_{1}\left(\ln W_{t}^{T}-\ln W^{A}{ }_{t}\right)+\beta_{2} X+\mu_{1}$

The difficulty in the calculation of a wage elasticity of the teacher supply is in calculating the individual counterfactual wage. As much as prospective teachers do not randomly become teachers, non-teachers are also not a random selection of workers. Therefore, we cannot simply assume that the counterfactual wage is the observed wage of the other occupation. Unobservable traits of the individuals will influence the individual wage, as well as observable characteristics.

Therefore, regression models with sample selection are commonly used for calculating unbiased counterfactual wages (see, e.g., Buchinsky, 2001): The reliability of the results of the wage elasticity greatly depends on the suitability of the statistical strategy chosen for identifying the selection into 
the teaching profession. Our study applies a much easier and more reliable way for the calculation of the individual counterfactual wages: We use wage expectation to calculate the individual wage differential for the prospective teachers, and we form the teacher wage for non-teachers by imputing a teaching wage to them on the basis of a wage regression for teachers (see equation 2). As the teacher wage is not dependent upon unobservable factors-cantons govern the wage, which in Switzerland depends only on age, qualifications, and family status-the estimate is relatively precise and should create no bias.

$\ln W^{T}{ }_{t}=\delta_{0}+\delta^{T}{ }_{1}$ Age ${ }_{t}+\delta^{T}{ }_{2}$ Qualifications $+\delta^{T}{ }_{3}$ Child $+\delta^{T}{ }_{4}$ Region $+\mu_{2}$

Wages of non-teachers in their original occupation we calculated by extrapolating current wage to the future. We assume for this purpose that individuals will remain in the workforce and will not change employers in the next 5 to 10 years. On the basis of a wage regression model for all employed workforce members in the SLFS, we determine the relevant parameters for experience and seniority. With these parameters we then extrapolate each individual wage to the future.

The existing literature suggests a positive wage elasticity of teacher supply. However, the literature in question relates only to first-career decisions, not to the career-change scenario. Career changes are based on a different set of experiences than labor market entry decisions. As preferences for nonmonetary aspects of an occupation differ between newcomers and changers, positive wage elasticity might not apply to changes of career.

\section{Results}

\subsection{Teachers' backgrounds}

We started by determining the comparison wage for each teacher by matching on the basis of SLFS data. The results of matching show that teachers represent a positive selection (ATT) on average, i.e., they earned significantly more in their former occupation than comparison subjects who did not change career to teaching (see table 2). Teacher trainees earned Swiss francs (CHF) 5,497 more on average per annum in their former occupation than comparison subjects (at the time of the study one CHF was roughly equivalent to one US dollar). The wage advantage over matched individuals is also positive for formerly self-employed individuals (about $18 \%$ of our sample); however, this estimate is not significantly different from zero because of the high standard error. This result is no surprise, given the high earnings heterogeneity among the self-employed population, and shows that the decision-making scenario for the formerly self-employed is much more difficult to model than that of former salaried employees. To take these differences into account, we conduct the following analyses 
separately for each of the two employment situations.

\section{[Table 2]}

In a further analysis, we regressed the individual wage differential determined by matching on the various characteristics of the teachers. This analysis shows us which individuals earned more or less in their former occupation than comparison subjects. The results in model 3 (Table 3) show that individuals in senior positions, specific industries, and certain regions earned significantly more than comparison subjects and other significantly less. Other characteristics, such as gender or qualifications, have no significant impact on wage differences for an average teacher.

\section{[Table 3]}

In model 4 (table 3) we interacted the level of qualification with a variable that shows whether prospective teachers had the option of working part-time in their former occupation - not whether they actually worked part-time. Interaction of the variables shows that, for individuals with ISCED $5 \mathrm{~A}$ qualifications (university or university of applied sciences), individuals who had the option of working part-time constitute a negative selection, while exactly the opposite holds true for those individuals who did not have that option. In other words, individuals with an upper secondary qualification and advanced occupation-specific qualification (ISCED 5B) constitute an average positive selection, while, for individuals with an academic qualification, positive selection applies only to those who did not previously have the option of working part-time. In contrast, subjects with an academic qualification who also had the option of working part-time are among those who earned significantly less than the comparison group in their former occupation. Thus, subjects having a university qualification having had no part-time option are people willing to give up an occupation in which they were highly financially successful because teaching gives them other ways of managing their time. Using similar response variables, e.g., importance of work-life balance for choosing the career as a teacher, is significantly more pronounced among university graduates with no prior opportunity to work part-time. These findings further support our interpretation of the results.

We also interacted the variable "option to work part time" with gender. Results show that the effect is significantly more pronounced for men than for women. Interaction with type of training (full-time versus sideline) further shows that the effect of the "part-time" variable is a determining factor only for teachers who are training as full-time teachers. This result makes sense in that subjects in sideline teacher training cannot, by definition, be individuals who do not have the option to work part-time.

In keeping with the hypotheses outlined earlier, the large effect sizes for the occupational categories 
show a consistent picture, The higher the average wage level in an occupation, the more likely that prospective teachers will constitute a negative selection, i.e. those who tended to earn less than comparison subjects, and vice versa. The average wage is about CHF 98,805 in the "technic and informatics occupations" category and CHF 89,022 in "management, administration, banking, and insurance occupations", and the coefficient is sharply negative in both cases. In contrast, the average wage level in the reference category "industry and craft industry" is CHF 69,922, and all of the occupation categories that deviate positively from the reference category feature average wages in the under CHF 80,000 range. This finding demonstrates that average wage in the former occupation is the main factor determining whether prospective teachers are more likely to constitute a positive or negative selection from their occupational sector.

\subsection{Teachers' wage expectations and the rate of return to teacher education}

We calculate the differences between wage expectations for teaching and original occupation by eliciting the respective expectations in the teacher survey. The results show that the average future teacher expects an annual wage benefit in teaching compared to their former occupation. This difference is significantly different from zero. However, the individual results with respect to relative wage expectations can be both positive and negative. Depending on the scenario, between one-quarter and one-third of prospective teachers expect to earn less than in their original occupation (see table 4).

\section{[Table 4]}

Even if the average teacher expects a positive wage differential due to the career change, that change is not necessarily monetarily beneficial, because the change requires an additional course of training with all the associated costs. We thus cannot give a precise estimation of the number of cases with a positive return on training investment. For sensitivity analysis, we calculated a "short-cut" return on training based on the following assumptions: The average prospective teacher is 40 years old, works until age 60 , and has a wage differential between teaching and former occupation that corresponds to the average figure. Assuming that the wage differential at 10 years continues to apply for the rest of the person's working life, and assuming an individual time preference of 5\%, we calculated returns for different reimbursement scenarios, i.e., whether or not the employer compensated the individual for the opportunity cost of training. The results show that a more than $30 \%$ reduction in wage during the two-year training at the trainee's expense pushes what would otherwise be a positive return into the negative range. In other words, even in the presence of average wage advantages, the return on training investment does not become positive unless the employer provides compensation for at least part of the opportunity costs (wage deficit generated as a result of the training period). Observations that show that some students attempt to minimize the earnings deficit by accepting teaching hours that are too high to be compatible with training, confirms these simulation results. 


\subsection{Wage elasticity of teacher supply}

While our analysis of wage expectations has already shown that individuals who change to teaching can expect a positive wage differential on average, this analysis is no indicator of elasticity of labor supply in teaching. In other words, without knowing the wage differential for people who do not change to teaching, we cannot know whether increasing the differential will interest more people in teaching.

The previously described method of calculating the wage differential for non-teachers shows that nonchangers would also on average benefit from a positive wage differential-i.e., would earn more--if they were to change to teaching. Table 5 shows the effect of this individual wage differential on the probability of becoming a teacher. The non-significantly different-from-zero wage differential reveals that individuals who changed to teaching were more likely to be those with a smaller wage differential in favor of teaching. This non-significant result is partly due, firstly, to teacher trainees including a relatively large percentage of individuals who are changing careers despite a loss of income. Second, a large number of non-teachers choose not to change to teaching despite a greater income advantage. If one excludes major differentials of several thousand CHF per monthly salary, the result can be interpreted as indicating that no monetary incentive exists for changing to teaching. Thus, non-monetary factors must be more important motives for changing careers.

In regards to the other factors, vocational teaching, unlike compulsory school teaching, does not display "feminization", of the occupation-specific part. In addition, in keeping with hypotheses one and two, lengthy tenure (duration of employment with the last employer) positively effects the probability of changing to teaching; however, the correlation is not linear. After twenty years of seniority, the probability of changing to teaching falls off.

\section{[Table 5]}

\section{Discussion}

The market for vocational teachers in Switzerland is unusual for a specific reason: Teachers of vocational subjects are required to demonstrate experience in their trade and, by definition, enter teaching as a result of changing careers. Therefore, establishing who will be willing to leave their original occupation to become a teacher at a later stage in their working life (the average age for qualifications as a vocational teacher is 40) is important, that is, who considers teaching of great enough appeal to compete with alternative occupations in private industry or the public sector. 
This paper focuses mainly on the relevance of monetary factors in making people more or less likely to decide in favor of changing careers to teaching, as monetary factors the main lever for educational policy makers to influence the equilibrium of supply and demand in the labor market for teachers. However, an analysis of monetary factors also allows us to mirror the relative importance of nonmonetary factors in informing the individual decision to change careers to teaching.

The finding that the average prospective teacher earned significantly more in his or her former occupation than comparison subjects supports the appeal of teaching. This result indicates that the average career changer does not change careers because he or she is (financially) unsuccessful or unproductive in the original occupation. Since a positive correlation between productivity in the original occupation and aptitude for teaching in vocational teaching is likely, this result has positive implications for the quality of vocational schools.

The results for all the analyses display significant heterogeneity, some of which can be explained. Positive selection for individuals with a university degree applies only to those individuals (largely male) who did not have the option for working part-time in their former occupation, while the other teachers with a university degree constitute a negative selection in terms of their relative earnings in their former occupations. This analysis shows the great relevance of non-monetary factors in informing the decision to enter teaching.

As to recruitment chances in the individual occupations: the higher the average wage level in an occupation, the larger the probability that individuals recruited from that occupation will rank among the low earners compared to similar peers. Teachers need to be recruited from sectors of industry with extremely different wage levels, but there is no major wage differential in the education system. Therefore, as a function of wage level in industry, equally "talented" teachers will most likely not be available for all the occupations taught in the VET system.

Although the average teacher tends to rank among the better earners in his or her original occupation, the majority of career changers expect to earn more as a teacher than in their original occupation. This finding shows that the average wage level at vocational schools can compete with average wage levels in industry. Again, however, substantial heterogeneity exists, given that between one-quarter and one-third of career changers are prepared to accept a cut in wage after changing to teaching. Probable explanation is again a very high relevance of non-monetary factors that make teaching a more attractive option, at least for some professionals.

Finally, the relevance of non-monetary factors for career decision-making is additionally apparent in the lack of positive labor supply elasticity, indicating that, at least within a certain range, higher 
wages are unlikely to trigger a higher demand for entering teaching. Wage increases are therefore likely to be of little use in solving a scarcity of teachers, being very expensive, as they will usually need to be granted to all those already engaged in the teaching profession. In contrast, non-monetary working conditions (e.g., flexible working hours) will be likely to highly enhance the appeal of teaching, suggesting that more attention should go to working conditions than to wage. Additionally, the calculation of the return on training investment for vocational teaching suggests that, if increasing the appeal of teaching via monetary factors becomes necessary, compensating for the opportunity cost of training will be a more effective and less expensive way of doing so. 


\section{References}

Abadie, A.; J.L. Herr; G.W. Imbens and D.M. Drukker (2004), NNMATCH: Stata module to compute nearest-neighbor bias-corrected estimators. Statistical Software Components, Boston College Department of Economics.

Becker, G.S. (1962), Investment in human capital: A theoretical analysis, Journal of Political Economy 70, 9-49.

Buchinsky, M. (2001), Quantile regression with sample selection: Estimating, women's return to education in the U.S., Empirical Economics 26, 87-113.

Burdett, K. (1978), A theory of employee job search and quit rates, The American Economic Review $68,212-220$.

Chevalier, A.; P. Dolton and S. Mcintosh (2007), Recruiting and retaining teachers in the UK: An analysis of graduate occupation choice from the 1960s to the 1990s, Economica 74, 69-96.

Chingos, M.M. and M.R. West (2010), Do more effective teachers earn more outside of the classroom?, CESifo Working Paper Series 2996.

Denzler, S. and S.C. Wolter (2009a), Laufbahnentscheide im Lehrberuf aus bildungsoekonomischer Sicht, [Career decisions in the teaching profession from an economics of education perspective], Zlatkin-Troitschanskaia et al. (Eds.), Professionalität - Bedingungen, Genese, Wirkungen und Messung [Professionalism - conditions, etiology, effects and measurement], Weinheim und Basel: Beltz Verlag, 641-654.

Denzler, S. and S.C. Wolter (2009b), Sorting into teacher education: how the institutional setting matters, Cambridge Journal of Education 39, 423-441.

Dolton, P. J. (1990), The economics of UK teacher supply: The graduate's decision, Economic Journal 100, 91-104.

Dolton, P.J. and T.-P. Chung (2004), The rate of return to teaching: How does it compare to other graduate jobs?, National Institute Economic Review 190, 89-103.

Falch, T. (2010), The elasticity of labor supply at the establishment level, Journal of Labor Economics 28, 237-266.

Geel, R.; J. Mure, and U. Backes-Gellner (2010), Specificity of occupational training and occupational mobility: an empirical study based on Lazear's skill-weights approach. Education Economics (2010) http://www.informaworld.com/10.1080/09645291003726483 (03.03.2011).

Hanushek, E.A. and R. R. Pace (1995), Who chooses to teach (and why)?, Economics of Education Review 14, 101-117.

Jovanovic, B. (1979), Job matching and the theory of turnover, Journal of Political Economy 87, 97290.

Kambourov, G. and I. Manovskii (2008), Rising occupational and industry mobility in the United States: 1968-97, International Economic Review 4, 41-79.

Lazear, E.P. (2009), Firm-specific human capital: A skill-weights approach. Journal of Political Economy 117, 914-940.

Longhi, S. and M. Brynin (2010), Occupational change in Britain and Germany, Labour Economics 17, 655-666.

Manski, C.F. (1987), Academic ability, earnings, and the decision to become a teacher: Evidence from the national longitudinal study of the high school class of 1972, Public Sector Payrolls, NBER Chapters, National Bureau of Economic Research, Inc., 291-316. 
Mortensen, D.T. (1986), Handbook of Labor Economics, Volume 2, Chapter Job search and labor market analysis, Amsterdam: Elsevier North-Holland, 849-919.

Murnane, R.J.; J.D. Singer; J.B. Willett; J.J. Kemple and R.J. Olsen (1991), Who will teach? Policies that matter, Cambridge, MA: Harvard University Press, 1991. xii + 187 pp.

Neal, D. (1999), The complexity of job mobility among young men, Journal of Labor Economics 17, 237-61.

Parrado, E.; A. Canera and E. N. Wolff (2007), Occupational and industrial mobility in the United States, Labour Economics 14, 435-455.

Podgursky, M.; R. Monroe and D. Watson (2004), The academic quality of public school teachers: an analysis of entry and exit behavior, Economics of Education Review 23, 507-518.

Rubinstein, Y. and Y. Weiss (2006), Post schooling wage growth: investment, search and learning, Volume 1 of Handbook of the Economics of Education, Amsterdam: Elsevier North-Holland, 1-67.

Sheldon, G. (2005), Der berufsstrukturelle Wandel der Beschaeftigung in der Schweiz 1970-2000: Ausmass, Ursachen und Folgen. [The structural change in employment in Switzerland 1970-2000: extent, causes and consequences] Neuchatel: BFS, 2005.

Stinebrickner, T.R. (2001), A dynamic model of teacher labor supply, Journal of Labor Economics 19, 196-230.

Wolter, S.C. and P. Ryan (2010), Handbook of the Economics of Education, Volume 3, Chapter Apprenticeship, Amsterdam: Elsevier North-Holland, 521-576.

Wolter, S.C. and S. Denzler (2004), Wage elasticity of the teacher supply in Switzerland, Brussels Economic Review 47, 387-408.

Wolter, S.C.; S. Denzler and B. A. Weber (2003), Betrachtungen zum Arbeitsmarkt der Lehrer in der Schweiz [Reflections on the teacher labor market in Switzerland], Vierteljahrshefte zur Wirtschaftsforschung / Quarterly Journal of Economic Research 72, 305-319. 
Table 1

Descriptive statistics - teacher variables

\begin{tabular}{|c|c|c|c|c|c|}
\hline & $\begin{array}{l}\text { all } \\
\text { teachers }\end{array}$ & $\begin{array}{l}\text { teachers without } \\
\text { self-employed }\end{array}$ & $\begin{array}{l}\text { sideline } \\
\text { teachers }\end{array}$ & $\begin{array}{l}\text { full-time } \\
\text { teachers }\end{array}$ & SLFS \\
\hline Female & 0.33 & 0.33 & 0.40 & 0.25 & 0.46 \\
\hline Age & 40.51 & 40.10 & 40.67 & 40.34 & 44.38 \\
\hline Gross yearly wage in CHF & 90,741 & 90,836 & 91,825 & 89,611 & 82,538 \\
\hline Upper secondary education & 0.08 & 0.08 & 0.09 & 0.07 & 0.63 \\
\hline ISCED 5b & 0.57 & 0.54 & 0.62 & 0.52 & 0.12 \\
\hline ISCED $5 a+6$ & 0.35 & 0.38 & 0.30 & 0.41 & 0.26 \\
\hline $\begin{array}{l}\text { Farming, forest economy, } \\
\text { and breeding }\end{array}$ & 0.03 & 0.02 & 0.03 & 0.03 & 0.02 \\
\hline Industry, craft industry & 0.28 & 0.28 & 0.23 & 0.33 & 0.12 \\
\hline Technic and informatics & 0.17 & 0.17 & 0.16 & 0.19 & 0.12 \\
\hline Building and mine & 0.08 & 0.07 & 0.10 & 0.05 & 0.06 \\
\hline $\begin{array}{l}\text { Commerce, transportation, } \\
\text { and traffic }\end{array}$ & 0.05 & 0.05 & 0.03 & 0.06 & 0.15 \\
\hline $\begin{array}{l}\text { Hotel business, catering, } \\
\text { personal service }\end{array}$ & 0.09 & 0.08 & 0.12 & 0.06 & 0.07 \\
\hline $\begin{array}{l}\text { Management, administration, } \\
\text { banking, and } \\
\text { insurance }\end{array}$ & 0.08 & 0.09 & 0.06 & 0.10 & 0.22 \\
\hline $\begin{array}{l}\text { Health, teaching, culture, } \\
\text { and science }\end{array}$ & 0.23 & 0.25 & 0.28 & 0.18 & 0.25 \\
\hline Sideline teachers & 0.51 & 0.49 & 1 & 0 & \\
\hline Observations & 390 & 330 & 199 & 191 & 36,251 \\
\hline
\end{tabular}


Table 2

Average wage difference (ATT)

\begin{tabular}{llll}
\hline \hline & ATT & Std. Err. & Observations \\
\hline Employed & 5,497 & $1,329^{* * *}$ & 330 \\
\hline & & & \\
\hline Self-employed & 7,165 & 6,274 & 60 \\
\hline
\end{tabular}

Matching variables: gender, age, degree of highest education, occupational field

$* \mathrm{p}<0.1, * * \mathrm{p}<0.05, * * * \mathrm{p}<0.001$ 
Table 3

Regression: individual matching on occupation

\begin{tabular}{lllll}
\hline \hline Effect on wage difference & $(1)$ & $(2)$ & $(3)$ & $(4)$ \\
\hline Female & $-7,273$ & $-6,611$ & $-4,029$ & $-2,180$ \\
& $(2,653)^{* * * *}$ & $(2,741)^{* *}$ & $(3,149)$ & $(3,252)$ \\
Reference category: Age & $\mathbf{4 1 - 5 0}$ years & & & \\
$21-30$ years & $-5,439$ & $-5,283$ & 671 & 673 \\
& $(3,042)^{*}$ & $(3,116)^{*}$ & $(3,688)$ & $(3,688)$ \\
$31-40$ years & $-2,659$ & $-2,528$ & 1,587 & 1,368 \\
& $(2,889)$ & $(2,889)$ & $(3,054)$ & $(3,055)$ \\
$51-60$ years & $-2,486$ & $-1,258$ & 458 & 95 \\
& $(7,840)$ & $(7,751)$ & $(5,938)$ & $(5,395)$
\end{tabular}

Reference category: Tertiary level B professional education and training (ISCED 5b)

Upper secondary education

ISCED5a+6

$(4,335)$
$-5,821$
$(3,045)^{*}$

4,269

, 742

ISCEDSa+6

$(3,045)^{*}$

1,195

$(5,747)$

Leader

$(3,323)$

$7,170 \quad 6,019$

$(2,731)^{* * *} \quad(2,711)^{* *}$

Reference category: Industry, craft industry

Farming, forest economy, and breeding

$1,935 \quad 3,939$

$(11,434) \quad(12,415)$

Technic and informatics

$-19,568 \quad-19,077$

Building and mine

Commerce, transportation, and traffic

Hotel business, catering, personal service

Management, administration, banking,

And insurance

Health, teaching, culture, and science

$(3,952)^{* * *}$

$6,582 \quad 7,815$

$(5,264) \quad(5,343)$

$-17,835 \quad-15,231$

$(6,849)^{* * *} \quad(6,853)^{* *}$

$1,989 \quad 2,648$

$(4,330) \quad(4,219)$

$-21,904 \quad-22,542$

$(5,5566)^{* * *} \quad(5,779)^{* * *}$

$-11,502 \quad-10,950$

$(4,287)^{* * *} \quad(4,331)^{* *}$

\section{Reference category: Lake Geneva-region}

Espace Midland

$4,267 \quad 3,847$

$(3,650) \quad(3,536)$

Northwest Switzerland

$-9,199 \quad-11,195$

$(4,112)^{* *} \quad(4,140)^{* * *}$

Zurich

$8,363 \quad 7,983$

$(3,567)^{* *} \quad(3,536)^{* *}$

Eastern Switzerland

$11,793 \quad 11,122$

$(4,735)^{* *} \quad(4,709)^{* * *}$

Central Switzerland

$(5,078) \quad(4,757)$

Interaction: upper sec. $\mathrm{x}$ option part-time

1186

Interaction: ISCED $5 \mathrm{a}+6 \mathrm{x}$ option part-time

$-14,224$

Interaction: ISCED 5b x option part-time

$-651$

$(3,582)$

Constant

$\underset{(2,428)^{* * *}}{9,682}$

11,572
$(2,414)^{* * *}$

$(5,760)$

3,555

\begin{tabular}{lllll}
\hline Observations & 330 & 330 & 330 & 330 \\
R2 & 0.03 & 0.04 & 0.25 & 0.28 \\
F & 2.84 & 2.96 & 5.18 & 5.01 \\
\hline
\end{tabular}

Robust standard errors in parentheses

Regressions (3) and (4) controlled for firm size, tenure, SLFS year

$* \mathrm{p}<.1, * * \mathrm{p}<.05, * * * \mathrm{p}<.001$ 
Table 4

Expected wage difference

\begin{tabular}{lccccc}
\hline \multicolumn{2}{c}{ Observations } & Mean & Std. Err. & Median & Share neg.diff. \\
All teachers & & & & \\
In 5 years & 339 & 3,152 & $1,309^{* *}$ & 3,000 & 0.32 \\
In 10 years & 339 & 6,101 & $1,620^{* * *}$ & 5,000 & 0.27 \\
& & & & \\
\hline & & & & \\
Without self-employed & & & \\
In 5 years & 289 & 3,735 & $1,378^{* * *}$ & 5,000 & 0.31 \\
In 10 years & 289 & 7,396 & $1,685^{* * *}$ & 9,000 & 0.25 \\
\hline$* \mathrm{p}<.1, * * \mathrm{p}<.05, * * * \mathrm{p}<.001$ & & &
\end{tabular}


Table 5

Wage elasticitiy of teacher supply

\begin{tabular}{lll}
\hline \hline Probit $(1=$ Teacher $)$ & Coefficient & Marginal Effects \\
\hline Expected wage difference $\left(\operatorname{lnW}^{\mathrm{T}}-\operatorname{lnW}^{\mathrm{A}}\right)$ & -.0126 & -.0004 \\
Female & $(.1434)$ & $(.0049)$ \\
& -.2592 & -.0083 \\
Age & $(.0955)^{* * *}$ & $(.0029)^{* * *}$ \\
& -.0601 & -.0021 \\
Age squared & $(.0632)$ & $(.0022)$ \\
Tenure & .0003 & .00001 \\
Tenure squared & $(.0008)$ & $(.00003)$ \\
Leader & .1113 & .0038 \\
& $(.0193)^{* * *}$ & $(.0007) * * *$ \\
& -.0029 & -.0001 \\
Refer & $(.0008)^{* * *}$ & $.00003)^{* * *}$ \\
& .0860 & .0029 \\
\end{tabular}

Reference category: Tertiary level B professional education and training (ISCED 5b)

ISCED5a+6

$-.2579$

$-.0094$

Reference category: Lake Geneva-region

Espace Midland

$-.3187$

$(.1015)^{* * *}$

$-.6724$

$(.1505)^{* * * *}$

Northwest Switzerland

$-.2519$

$(.1068)^{* *}$

$-.9029$

$(.1763)^{* * *}$

$-.9506$

$(.2072)^{* * * *}$

$(.0033) * * *$

Eastern Switzerland

$-.0154$

$(.0049)^{* * *}$

$-.0249$

$(.0047)^{* * *}$

$-.0128$

$(.0053)^{* *}$

$-.0283$

$(.0045)^{* * *}$

$-.0289$

$(.0045) * * *$

Reference category: Industry, craft industry

Farming, forest economy, and breeding

$-.6946$

$(.3127)^{* *}$

$-.9100$

$(.1232)^{* * *}$

$-.5996$

$(.1835) * * *$

Building and mine

$-1.0703$

Commerce, transportation, and traffic

$(.1512)^{* * *}$

Hotel business, catering, personal service

$-.7807$

$(.2103) * * *$

$-1.1793$

Management, administration, banking,

$(.1401)^{* * *}$

$-1.0979$

Health, teaching, culture, and science

$(.1271)^{* * *}$

$-.0638$

$(.0196)^{* *}$

$-.0729$

$(.0132)^{* * * *}$

$-.0585$

$(.0154)^{* * * *}$

$-.0776$

$(.0131)^{* * *}$

$-.0688$

$(.0149)^{* * *}$

$-.0800$

$(.0131)^{* * * *}$

$-.0783$

$(.0132)^{* * * *}$

Reference category: SLFS 2008

SLFS 2004

$-.1379$

$-.0046$

(.0915)

(.0029)

$-.3475$

$-.0105$

SLFS 2006

$(.0987) * * *$

$(.0027)^{* * * *}$

Constant

(1.2452)

Observations

8'890

$8^{\prime} 890$

People with ISCED 5b or higher included

Robust standard errors in parentheses

$* \mathrm{p}<.1, * * \mathrm{p}<.05, * * * \mathrm{p}<.001$ 